\title{
Planting Dates and Transplant Establishment Methods on Early-yield Strawberry in West-central Florida
}

\author{
Emmanuel A. Torres-Quezada ${ }^{1}$, Lincoln Zotarelli ${ }^{1,5}$, \\ Vance M. Whitaker ${ }^{1,2}$, Rebecca L. Darnell ${ }^{1}$, Bielinski M. Santos ${ }^{1,4}$, \\ and Kelly T. Morgan ${ }^{3}$
}

ADDITIONAL INDEX WORDs. Fragaria $\times$ ananassa, crop protectant, kaolin clay, sprinkler irrigation, bare-root transplant, water savings

SUMMARY. Earlier fall planting dates for strawberry (Fragaria $\times$ ananassa) in westcentral Florida tend to promote earlier onset of flowering and fruiting. However, warm air temperatures $\left(>28{ }^{\circ} \mathrm{C}\right)$ can result in excessive growth and runner production. Sprinkler irrigation is a common practice to reduce air temperature in the first 10 tol5 days after transplanting, requiring large volumes of irrigation water. An alternative to sprinkler irrigation is the application of crop protectants such as kaolin clay after transplanting. The objectives of this study were to determine the optimal planting dates and to assess the most appropriate establishment practices for strawberry bare-root transplants in Florida. Four establishment practices-10 days of sprinkler irrigation (DSI), 10 DSI + kaolin clay, 7 DSI, and 7 DSI + kaolin clay were evaluated for 'Florida Radiance' and Sweet Sensation ${ }^{\circledR}$ 'Florida 127' transplanted in mid September, late September, and early October in consecutive seasons. For 'Floridal 27', September planting dates increased early yield compared with early-October traditional planting dates, with no difference in total yield. Seven DSI followed by the foliar application of kaolin clay at day 8 was also found to increase early yield compared with 10 DSI for strawberry establishment, with annual water savings of $108.7 \mathrm{~mm}$.

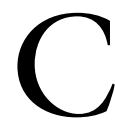
alifornia and Florida are the two leading producers of strawberries in the United States (U.S. Department of Agriculture, 2012). The Florida farm gate crop value was about $\$ 290$ million in 2015 , from a crop grown on $\approx 10,700$ acres (U.S. Department of Agriculture, 2017). The highest strawberry prices for growers in west-central Florida occur from late November to mid December (Tanino and Wang, 2008; Wu et al., 2012). Early strawberry planting (20-25 Sept.) is increasing in west-central Florida with the goal of increasing yield during this period. Although earlier fall planting dates tend to promote earlier onset of flowering and fruiting (Poling, 1993), the warm air temperatures

\footnotetext{
${ }^{1}$ Horticultural Sciences Department, IFAS, University of Florida, Gainesville, FL 32611

${ }^{2}$ Gulf Coast Research and Education Center, IFAS, University of Florida, 14625 CR 672, Wimauma, FL 33598

${ }^{3}$ Southwest Florida Research and Education Center, IFAS, University of Florida, 2685 State Road 29 North, Immokalee, FL 34142

${ }^{4}$ Former associate professor.

${ }^{5}$ Corresponding author. E-mail: lzota@ufl.edu.

https://doi.org/10.21273/HORTTECH04079-18
}

experienced in west-central Florida during this time cause excessive running and plant growth, and reduce flower initiation and fruit yield (Heide et al., 2013). This situation presents a major challenge for strawberry production in this area.

Planting date recommendations for central Florida range between 25 Sept. and 25 Oct., depending on the cultivar (Whitaker et al., 2017). However, modern strawberry breeding programs focus on decreasing the requirement for low air temperature and multiple photoinductive cycles for flower bud induction. 'Strawberry Festival' and 'Florida Radiance' are the standard cultivars grown in Florida, mainly because of their large fruit size and flavor. Sweet Sensation ${ }^{\circledR}$ 'Florida $127^{\prime}$ is the newest released cultivar from the University of Florida Strawberry Breeding Program, showing improvement in fruit size and flavor compared with traditional cultivars (Kelly et al., 2016). As new heattolerant strawberry cultivars are released, greater early yield might be obtained as early planting dates are implemented (Rubinstein, 2015; Whitaker et al., 2014).

The most commonly used transplant type in Florida is bare root (Bish and Cantliffe, 2002; Bish et al., 1997). Bare-root leaf-on transplants promote earlier yield compared with those with leaves removed, but typically require high volumes of water via sprinkler irrigation after transplanting (Bish et al., 1997). Between 8 and $14 \mathrm{~h} \cdot \mathrm{d}^{-1}$ of continuous sprinkler irrigation are used to reduce the air temperature around the strawberry crown and keep leaves moist (Bish and Cantliffe, 2002; Bish et al., 1997). This irrigation practice accounts for one third of the total water required by the crop throughout the season (Hochmuth et al., 2006a), and it can impact the crop negatively by increasing disease dissemination and leaching nutrients out of the rooting zone (Bish et al., 1997; Hochmuth et al., 2006b). Lack of uniformity of bare-root transplants combined with plant damage created by sprinkler irrigation can contribute to reduction of early yield (Bish et al., 2001).

An alternative to sprinkler irrigation for plant establishment is the application of crop protectants after transplant (Santos et al., 2012b). Crop protectants provide a shield that reduces environmental stress on plants. During transplant establishment, naturally occurring materials such as kaolin clay, calcium carbonate, or aluminum silicate can be

\begin{tabular}{llll}
\hline $\begin{array}{l}\text { Units } \\
\begin{array}{l}\text { To convert U.S. to SI, } \\
\text { multiply by }\end{array}\end{array}$ & U.S. unit & SI unit & $\begin{array}{l}\text { To convert SI to U.S., } \\
\text { multiply by }\end{array}$ \\
\hline 0.3048 & $\mathrm{ft}$ & $\mathrm{m}$ & 3.2808 \\
3.7854 & $\mathrm{gal}$ & $\mathrm{L}$ & 0.2642 \\
2.54 & inch $(\mathrm{es})$ & $\mathrm{cm}$ & 0.3937 \\
25.4 & inch(es & $\mathrm{mm}$ & 0.0394 \\
1.1209 & $\mathrm{lb} / \mathrm{acre}$ & $\mathrm{kg} \cdot \mathrm{ha}^{-1}$ & 0.8922 \\
0.0254 & $\mathrm{mil}(\mathrm{s})$ & $\mathrm{mm}$ & 39.3701 \\
28.3495 & $\mathrm{oz}$ & $\mathrm{g}$ & 0.0353 \\
62.5000 & $\mathrm{Oz} / \mathrm{lb}$ & $\mathrm{g} \cdot \mathrm{kg}^{-1}$ & 0.0160 \\
2.2417 & $\mathrm{ton}(\mathrm{s}) / \mathrm{acre}$ & $\mathrm{Mg} \cdot \mathrm{ha}^{-1}$ & 0.4461 \\
$\left({ }^{\circ} \mathrm{F}-32\right) \div 1.8$ & ${ }^{\circ} \mathrm{F}$ & ${ }^{\circ} \mathrm{C}$ & $\left({ }^{\circ} \mathrm{C} \times 1.8\right)+32$
\end{tabular}


applied on top of the plant canopy. These materials act as reflective barriers to decrease ultraviolet and infrared radiation, therefore reducing heat stress on plants (Glenn and Puterka, 2005; Glenn et al., 2002, 2003). Crop protectants are widely used to reduce sunburn and decrease pest incidence on fruit such as apple (Malus domestica), pear (Pyrus sp.), tomato (Solanum lycopersicum), and pomegranate (Punica granatum) (Cantore et al., 2009; Glenn and Puterka, 2005; Glenn et al., 2002; Melgarejo et al., 2004). Previous studies reported that the application of kaolin clay reduced evapotranspiration rate and fruit temperature by 2 to $5{ }^{\circ} \mathrm{C}$ in apple and pomegranate (Glenn et al., 2002; Melgarejo et al., 2004; Wand et al., 2006). Santos et al. (2012b) reported 98\% plant survival and no reduction in early yield in strawberry plants when kaolin clay was applied during establishment after 6 DSI for early October planting. Given the warmer maximum air temperatures of September compared with October (Fig. 1), it could be hypothesized that the effect of kaolin clay on plant establishment and early yield may be temperature dependent because the warmer air temperature associated with earlier planting (mid September) in strawberry production may influence the crop response to the application of the protectant.

To obtain the greatest possible early yield in Florida strawberry production, it is necessary to determine the most adequate combination of production techniques. The objectives of this study were to determine optimal planting dates for early strawberry production; determine the most adequate establishment practices for bare-root, leaf-on transplants for west-central Florida; and evaluate the effect of reduced irrigation water for establishment in strawberry production.

\section{Materials and methods}

Three field experiments were conducted in consecutive seasons between 2013 and 2016 at the Gulf Coast Research and Education Center of the University of Florida located at Balm, FL (lat. $27^{\circ} 75^{\prime} \mathrm{N}$, long. $\left.82^{\circ} 22^{\prime} \mathrm{E}\right)$. The soil at the experimental site is classified as a Myakka fine sand, siliceous hyperthermic Oxyaquic Alorthod (U.S. Department of
Agriculture, 2018) with les than $1.5 \mathrm{~g} \cdot \mathrm{kg}^{-1}$ soil organic matter and a $\mathrm{pH}$ of 6.6 (Torres-Quezada et al., 2015). In late August of every season, the soil was tilled twice to an approximate depth of 8 inches (BP42l double disk; Kenco Manufacturing, Atoka, OK) before planting and pressed beds were formed: 27 inches wide at the base, 24 inches wide at the top, and 10 inches high, spaced $4 \mathrm{ft}$ apart on center. During bed pressing, beds were fumigated with 1,3-dichloropropene $(63.4 \%)+$ chloropicrin $(34.7 \%)$ at a rate of $250 \mathrm{lb} /$ acre $\left(\right.$ Telone $^{\circledR}$ C-35; Dow AgroScience, Indianapolis, IN). Immediately after fumigation, beds were covered with high-density black polyethylene mulch film (thickness, 1 mil; Intergro Co., Clearwater, FL). At the same time, one drip tape line $\left(0.5 \mathrm{~L} \cdot \mathrm{h}^{-1}\right.$ per emitter, 12 inches between emitters; Rivulis, Gvat, Israel) was laid on the top center of the bed, directly under the polyethylene film. The drip tape delivered daily irrigation and fertilizer to the plants. For the establishment stage, the experimental area was set with $17 \mathrm{~L} \cdot \mathrm{min}^{-1}$ sprinkler heads spaced on a grid $48 \times$ $48 \mathrm{ft}$ apart (WR-32; Wade Rain, Medley, FL).

Bare-root transplants with three to five leaves were obtained from California (Crown Nursery, Red Bluff, CA). In 2013-14, 'Florida Radiance' (sold as 'Florida Fortuna' outside the United States and Canada), 'Strawberry Festival', Sweet Sensation $^{\circledR}$ 'Floridal27' (hereafter referred to as 'Floridal27'), and WinterStar 'FL 05-107' (hereafter referred to as 'FL 05-107') were planted on 19 Sept., 26 Sept., and 3 Oct. 2013, as a representation of mid-September, late-September, and early-October planting dates. During the nursery stage in 2013-14, plants for the 19 Sept. planting date received $\approx 166 \mathrm{~h}$ of chilling in the nursery before harvest (determined as hours with air temperatures between 7 and $15^{\circ} \mathrm{C}$ ). For the 26 Sept. and 3 Oct. plantings, transplants received $\approx 228$ and $312 \mathrm{~h}$ of chilling in the nursery, respectively. In 2013-14, transplants were established with 10 DSI and 7 DSI + application of $25 \mathrm{lb} /$ acre of kaolin clay (Surround ${ }^{\circledR}$ WP; Tessenderlo Kerley, Phoenix, AZ) at day 8. Transplants were planted in standard raised beds in double rows, with 16 inches of in-row spacing.

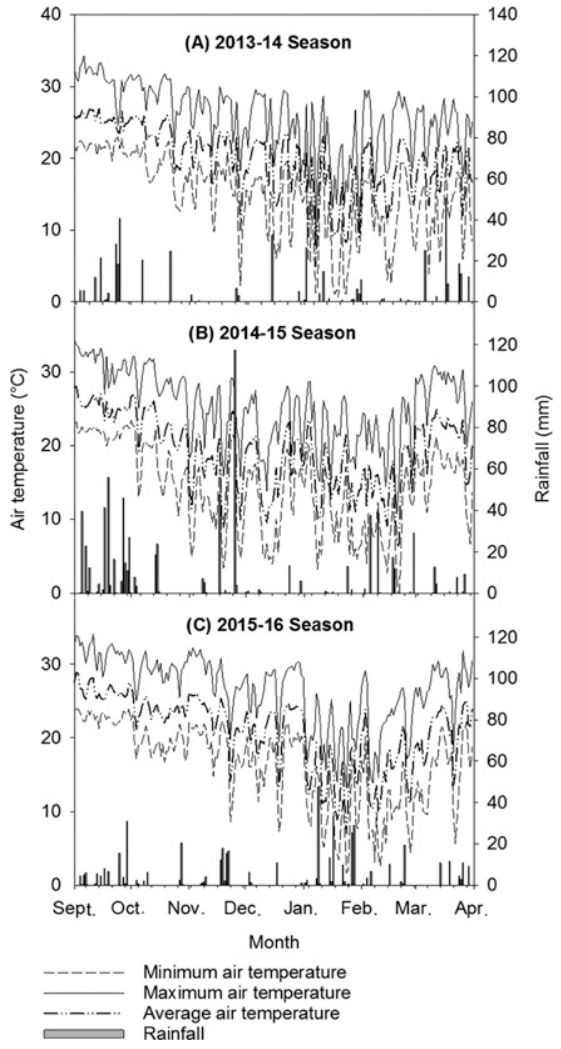

Fig. 1. Average, minimum, and maximum air temperatures and rainfall at the experimental site, in Balm, FL, from the (A) 2013-14, (B) 2014-15, and (C) 2015-16 strawberry growing seasons. (1.8 $\times$ $\left.{ }^{\circ} \mathrm{C}\right)+32={ }^{\circ} \mathrm{F}, 1 \mathrm{~mm}=0.0394$ inch.

In 2013-14, experimental units were $16 \mathrm{ft}$ long, with 20 plants for harvest. During transplant establishment, 10 DSI treatments received $362.3 \mathrm{~mm}$, while 7 DSI received $253.6 \mathrm{~mm}$. Plots were harvested twice per week starting on 13 Nov. 2013. Early marketable yield was defined as the cumulative marketable weight of all harvests until 15 Dec., whereas total marketable yield consisted of the cumulative weight of 20 harvests. A marketable fruit was defined as a fruit of at least $10 \mathrm{~g}$, without visible blemishes, and at least $75 \%$ external red color. Average fruit weight was determined by dividing the total marketable fruit weight of each treatment by its corresponding fruit number.

In the 2014-15 and 2015-16 seasons, 'Strawberry Festival' and 'FL 05-107' were eliminated from the study. 'Florida Radiance' and 'Floridal27' were planted on 23 Sept., 30 Sept., and 7 Oct. In the 2014-15 season, transplants received 
$\approx 147$ h of chilling in nursery for the 23 Sept. planting, $238 \mathrm{~h}$ for the 30 Sept. planting, and $285 \mathrm{~h}$ for the 7 Oct. planting. In the 2015-16 season, transplants received $\approx 170 \mathrm{~h}$ of chilling in the nursery for the $23 \mathrm{Sept}$. planting, $208 \mathrm{~h}$ for the 30 Sept. planting, and $262 \mathrm{~h}$ for the 7 Oct. planting. Transplants were established with 10 DSI, 10 DSI + kaolin clay, 7 DSI, and 7 DSI + kaolin clay. During establishment, sprinkler irrigation was applied $8 \mathrm{~h} \cdot \mathrm{d}^{-1}$ according to treatments in all seasons. In 201415 and 2015-16, experimental units increased to $26 \mathrm{ft}$ long with 20 plants for harvest and 21 plants for biomass measurements.

In 2014-15 and 2015-16, dry biomass of shoots and runners was collected at 4, 8, 12, 16, and 20 weeks after transplant (WAT) using three randomly selected plants per plot. Plots were harvested twice per week starting on 18 Nov. 2014 and 19 Nov. 2015. Early and total marketable yield and average fruit weight were collected as described earlier. Rainfall was collected with a tipping bucket (H-340; Campbell Scientific, Logan, UT) for all three seasons, installed near the experimental site (Florida Automated Weather Network, 2018). During the 2015-16 season, air temperature was measured during plant establishment at three locations: on top of the plastic bed, between the plastic-mulch and the soil, and 4 inches deep in the soil. Air temperature was measured every $15 \mathrm{~min}$ using temperature probes connected to a data logger (WatchDog Al50; Spectrum Technologies, Aurora, IL).

In all seasons, plots received 150 $\mathrm{lb} /$ acre of nitrogen $(\mathrm{N})$ with a solution containing nutrient levels of $2.3 \% \mathrm{~N}, 1 \%$ phosphorus, $6.5 \%$ potassium, $2 \%$ calcium, $0.4 \%$ magnesium, $0.02 \%$ boron, $0.04 \%$ manganese, and $0.02 \%$ zinc (Santos et al., 2012a). Daily fertilizer applications started 2 WAT through the drip lines using a hydraulic injector (Dosatron, Clearwater, FL) to pump concentrated stock solution into the irrigation water using a dilution rate of $1: 50(\mathrm{v} / \mathrm{v})$. In late October of all seasons, the remaining kaolin clay was washed off the beds using the same sprinkler irrigation described earlier if rainfall did not occur. Irrigation volume was the equivalent to the average reference evapotranspiration for west- central Florida from October to March (Simonne and Dukes, 2009) and was split equally into two daily irrigation cycles, starting at 0800 and $1300 \mathrm{HR}$, respectively.

All trials followed a split-split plot design, with planting dates as the main plot, establishment practice as the subplot, and cultivars as the sub-subplot. In all seasons, treatments were analyzed using analysis of variance $(P \leq 0.05)$. Season and treatments were analyzed for interactions. As a result of significant interaction between season and treatments, analyses were performed separately for each season. Planting date, transplant type, and cultivar were analyzed for main and interaction effects. In case of significant effects, treatment means were separated using Fisher's protected least significant difference test (Statistix, version 9; Analytical Software, Tallahassee, FL).

\section{Results \\ Plant dry biomass}

At 4 WAT in 2014-15, there was no effect of planting date or establishment practice on strawberry shoot dry biomass or runner dry biomass, averaging 14.2 and $0.7 \mathrm{~g} /$ plant, respectively. Shoot dry biomass was greater in 'Floridal27' ( $16.1 \mathrm{~g} /$ plant $)$ compared with 'Florida Radiance' (12.4 $\mathrm{g} /$ plant) at 4 WAT. There was no interaction among planting date, establishment practice, and cultivar for shoot biomass at 4 WAT. Likewise, there was no effect of planting date and establishment practice on runner biomass at $4 \mathrm{WAT}$, with an average of 0.7 runner per plant. 'Florida127' had a greater runner production (1.1 runners per plant) than 'Florida Radiance' ( 0.3 runners per plant) at 4 WAT.

At 8 WAT, September plantings had a greater shoot dry biomass than early October (Table 1). There was no effect of establishment practice on shoot dry biomass. However, 'Floridal27' had 23\% greater shoot biomass production than 'Florida Radiance'. There was no effect of planting date or establishment practice on runner biomass, but 'Floridal27' continued to produce more runners than 'Florida Radiance' (data not shown). For shoot dry biomass at 12 WAT, there was an interaction between establishment practice and cultivar, and planting date and cultivars (Table 1). Furthermore, the interaction between planting date and cultivar for shoot biomass continued at 16 and 20 WAT (Table 1 ).

At 12 WAT, 'Florida Radiance' had the same shoot biomass across all establishment practices, with an average of $15.8 \mathrm{~g} /$ plant. Conversely, 'Floridal27' had a greater shoot biomass when established with 10 DSI + kaolin clay $(22.5 \mathrm{~g} /$ plant $)$ and 7 DSI + kaolin clay ( $16 \mathrm{~g} /$ plant). Overall, 'Floridal27' had greater shoot biomass than 'Florida Radiance', averaging 22.4 and $15.8 \mathrm{~g} /$ plant, respectively (data not shown).

In 2015-16, shoot dry biomass was similar to the 2014-15 season in that 'Floridal27' had greater shoot biomass than 'Florida Radiance'. There was no effect of planting date and establishment practice on shoot biomass at 4, 16, and 20 WAT. At 8 and 12 WAT, late-September plantings had greater shoot biomass than mid September and early October, whereas at 12 WAT, 10 DSI had greater shoot biomass than 10 DSI + kaolin clay, 7 DSI, and 7 DSI + kaolin clay. There was no interaction among factors for any of the dates (Table 1 ).

For the interaction between planting date and cultivar, at 12 and 16 WAT of 2014-15, planting date did not affect shoot biomass of 'Florida Radiance'. However, 'Florida 127' had the greatest shoot biomass when planted in late September and early October (Table 2). Furthermore, 'Floridal27' had greater shoot biomass than 'Florida Radiance' across all planting dates, except for early October at 16 WAT (Table 2). At 20 WAT, there was no difference between 'Florida Radiance' and 'Floridal27' in mid September and early October, whereas 'Floridal27' had greater shoot biomass than 'Florida Radiance' in late September (Table 2).

\section{Early and total yield}

2013-14 SEASON. In 2013, average air temperature decreased from $25.4{ }^{\circ} \mathrm{C}$ in September to $19.4{ }^{\circ} \mathrm{C}$ in December. Air temperature in September was also the warmest, with a maximum of $34.2{ }^{\circ} \mathrm{C}$. The coolest minimum air temperature was in January $\left(0.7^{\circ} \mathrm{C}\right)$. Monthly cumulative rainfall values during Sept., Oct., Nov., and Dec. 2013 were 140, $45.2,13.7$, and $38.4 \mathrm{~mm}$, respectively (Fig. 1A). 
Table 1. Effect of planting date, establishment practice, and cultivar on shoot dry biomass of strawberry in Balm, FL, during the 2014-15 and 2015-16 growing seasons.

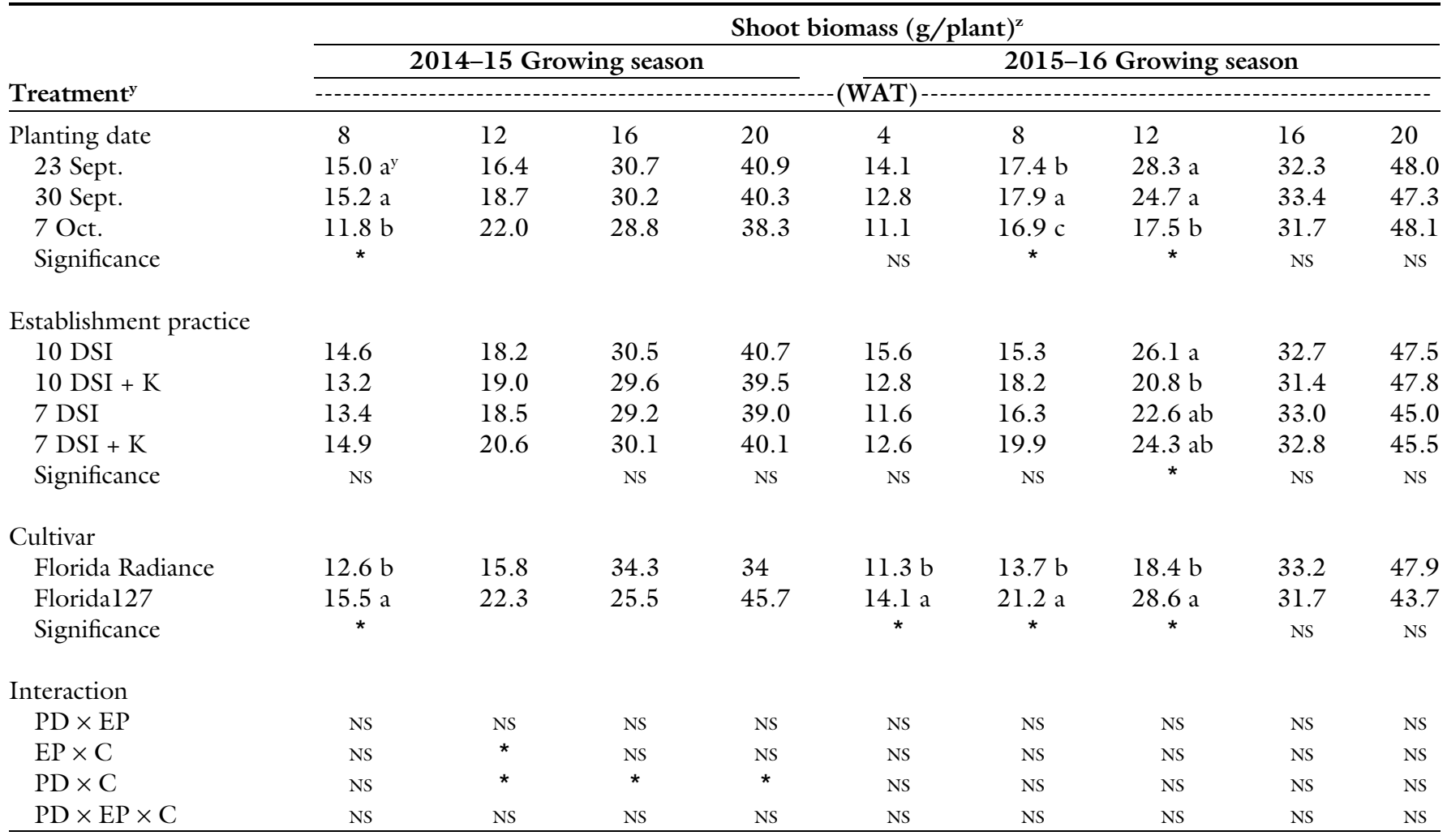

${ }^{\mathrm{z}} \mathrm{lg}=0.0353 \mathrm{oz}$.

y Values followed by the different letters (columns) indicate that the means of planting dates or establishment practice are significantly different $(P \leq 0.05)$ according to Fisher's protected least significant difference test within WAT.

NS, *Nonsignificant or significant at $P \leq 0.05$, respectively.

$\mathrm{WAT}=$ weeks after treatment; $\mathrm{DSI}=$ days of sprinkler irrigation; $\mathrm{K}=$ kaolin clay application on day 8 or 11 of establishment irrigation; $\mathrm{PD}=$ planting date; EP $=$ establishment practice; $\mathrm{C}=$ cultivar.

Table 2. Effect of planting date and cultivar on shoot dry biomass at 12, 16, and 20 weeks after transplant (WAT) in strawberry in Balm, FL, during the 2014-15 growing season.

\begin{tabular}{|c|c|c|c|c|c|c|}
\hline \multirow[b]{3}{*}{ Planting date } & \multicolumn{6}{|c|}{ Shoot biomass $(\mathrm{g} / \text { plant })^{\mathrm{z}}$} \\
\hline & \multicolumn{2}{|c|}{12 WAT } & \multicolumn{2}{|c|}{$16 \mathrm{WAT}$} & \multicolumn{2}{|c|}{$20 \mathrm{WAT}$} \\
\hline & Florida Radiance & Florida127 & Florida Radiance & Florida127 & Florida Radiance & Floridal27 \\
\hline 30 Sept. & $15.4 \mathrm{~B} \mathrm{a}$ & $22.0 \mathrm{~A} \mathrm{ab}$ & $22.4 \mathrm{~B} \mathrm{a}$ & $37.9 \mathrm{~A} \mathrm{a}$ & $29.9 \mathrm{~B} \mathrm{a}$ & $50.9 \mathrm{~A} \mathrm{a}$ \\
\hline 7 Oct. & $17.8 \mathrm{~B} \mathrm{a}$ & $26.4 \mathrm{~A} \mathrm{a}$ & $27.6 \mathrm{~A} \mathrm{a}$ & $29.8 \mathrm{~A} \mathrm{~b}$ & $36.5 \mathrm{~A} \mathrm{a}$ & 39.9 A b \\
\hline
\end{tabular}

${ }^{\mathrm{z}} \mathrm{lg}=0.0353 \mathrm{oz}$.

${ }^{y}$ Values followed by different uppercase letters (rows) indicate significantly different means $(P \leq 0.05)$ according to Fisher's protected least significant difference (LSD) test within planting date. Values followed by different lowercase letters (columns) indicate significantly different means $(P \leq 0.05)$ according to Fisher's protected LSD test within cultivar.

EARLY YIELD. In 2013-14, there was an interaction between planting dates and cultivars for early yield. Planting date had no effect on 'Florida Radiance', 'Strawberry Festival', and 'FL 05-107' early yield, with an average yield of $1.9,1.7$, and 0.9 $\mathrm{Mg} \cdot \mathrm{ha}^{-1}$, respectively. However, 'Florida127' planted in mid September and late September had greater early yield than when planted in early October (Table 3). Within planting dates, there was no difference between 'Florida Radiance' and 'Floridal27' planted in mid September;
'FL 05-107' had the lowest yield. 'Florida 127' had the greatest yield when planted in late September, with no difference between 'Florida Radiance' and 'Strawberry Festival'. In early October, there was no difference in early yield among 'Florida Radiance', 'Floridal27', and 'Strawberry Festival', whereas 'FL 05-107' had the lowest early yield. In general, fruit number explained the differences in early yield (Table 3 ).

Total YIELD. There was no interaction among planting dates, establishment practice, or cultivars for total yield, total fruit number, or average fruit weight (data not shown). There was no effect of planting date on total yield, which averaged $11.9 \mathrm{Mg} \cdot \mathrm{ha}^{-1}$. Furthermore, establishment practice did not affect total yield, averaging $12.1 \mathrm{Mg} \cdot \mathrm{ha}^{-1}$. 'Florida Radiance' and 'Floridal27' had the greatest total yield, averaging 14.7 Mg.ha' ${ }^{-1}$ 'FL 05-107' had a total yield of $11.4 \mathrm{Mg} \cdot \mathrm{ha}^{-1}$, whereas 'Strawberry Festival' had the lowest total yield with $7.7 \mathrm{Mg} \cdot \mathrm{ha}^{-1}$.

Given the higher early and total yield of 'Florida Radiance' and 
Table 3. Effect of planting date and cultivar on early yield and early fruit number of strawberry in Balm, FL, during the 201314 growing season.

\begin{tabular}{|c|c|c|c|c|c|c|}
\hline \multirow[b]{3}{*}{ Cultivar } & \multicolumn{6}{|c|}{ Planting date } \\
\hline & 19 Sept. & 26 Sept. & 3 Oct. & 19 Sept. & 26 Sept. & 3 Oct. \\
\hline & \multicolumn{3}{|c|}{ Early yield $\left(\mathrm{Mg} \cdot \mathrm{ha}^{-1}\right)^{\mathrm{z}}$} & \multicolumn{3}{|c|}{ Early fruit (no./plant) } \\
\hline Floridal27 & $2.5 \mathrm{~A} \mathrm{a}$ & $2.9 \mathrm{~A} \mathrm{a}$ & $1.8 \mathrm{~B} \mathrm{a}$ & $3.5 \mathrm{~A} \mathrm{a}$ & $3.7 \mathrm{~A} \mathrm{a}$ & $2.5 \mathrm{~B} \mathrm{a}$ \\
\hline Strawberry Festival & $1.7 \mathrm{~A} \mathrm{~b}$ & $1.7 \mathrm{~A} \mathrm{~b}$ & $1.5 \mathrm{~A} \mathrm{ab}$ & $3.2 \mathrm{~A} \mathrm{a}$ & $3.1 \mathrm{~A} \mathrm{~b}$ & $2.6 \mathrm{~A} \mathrm{a}$ \\
\hline FL 05-107 & $0.8 \mathrm{~A} \mathrm{c}$ & $0.9 \mathrm{~A} \mathrm{c}$ & $1.2 \mathrm{~A} \mathrm{~b}$ & $1.5 \mathrm{~A} \mathrm{~b}$ & $1.4 \mathrm{~A} \mathrm{c}$ & $2.1 \mathrm{~A} \mathrm{a}$ \\
\hline
\end{tabular}

${ }_{\mathrm{z}} 1 \mathrm{Mg} \cdot \mathrm{ha}^{-1}=0.4461 \mathrm{ton} / \mathrm{acre}$.

${ }^{y}$ Values followed by different uppercase letters (rows) indicate significantly different means $(P \leq 0.05)$ according to Fisher's protected least significant difference (LSD) test within cultivar for early yield or early fruit separately. Values followed by different lowercase letters (columns) indicate significantly different means $(P \leq 0.05)$ according to Fisher's protected LSD test within planting dates.

'Florida127' compared with 'Strawberry Festival' and 'FL 05-107', the latter two cultivars were eliminated from the study. Because there was no difference between 10 DSI and 7 DSI + kaolin clay for any of the measured variables, a 7 DSI control and a 10 DSI + kaolin clay treatment were added in the following 2014-15 and 201516 seasons to measure the kaolin clay effect.

2014-15 Season. Air temperature in Sept. 2014 was similar to Sept. 2013 , with an average of $25.4{ }^{\circ} \mathrm{C}$, a maximum of $34.5^{\circ} \mathrm{C}$, and a minimum of $19.9^{\circ} \mathrm{C}$. However, air temperature in Oct., Nov., and Dec. 2014 was consistently cooler than 2013 (Fig. 1A and B). The coolest minimum air temperature was in Jan. $2015\left(1.7^{\circ} \mathrm{C}\right)$. Cumulative rainfall during 2014-15 was $\approx 164$ mm more than the 2013-14 season, with a total of $757.9 \mathrm{~mm}$ (Fig. 1B).

EARLY YIELD. In 2014-15, there was no interaction among factors, but there were clear effects of planting date, establishment practice, and cultivar. Mid-September planting had the greatest early yield, followed by late September and early October (Table 4). For establishment practices, plants established with 10 DSI had a $14 \%$ less early yield than the rest of the treatments. 'Florida 127' had a 16\% greater early yield than 'Florida Radiance'. These early-yield results are consistent with effects observed on early fruit numbers and average fruit weights (Table 4). Fruit weight in the 10 DSI + kaolin clay and 7 DSI + kaolin clay treatments were greater than in the 10 and 7 DSI treatments.

TotAL YIELD. There was a threeway interaction for total yield and total fruit number. For mid-September planting, there was no difference in total yield of 'Florida Radiance' and 'Florida 127' regardless of the establishment practice (Table 5 ). In late September, 'Florida Radiance' established with 10 DSI + kaolin clay had the lowest total yield compared with 10 DSI, 7 DSI, and 7 DSI + kaolin clay (Table 5). 'Florida 27' had the lowest total yield when planted with 10 DSI compared with the rest of the establishment treatments (Table 5). In early October, 'Florida Radiance' established with 10 DSI and 10 DSI + kaolin clay had a greater total yield than 7 DSI and 7 DSI + kaolin clay (Table 5). 'Floridal27' showed no difference in total yield regardless of the establishment practice in early October. Mid-September planting had the greatest total fruit number regardless of the establishment practice (Table 5). The increase in yield within establishment practice was related to an increase in fruit size; early fruit number was unaffected by establishment practice. During establishment, 10 DSI treatments received $362 \mathrm{~mm}$ water whereas 7 DSI + kaolin clay received $254 \mathrm{~mm}$, resulting in a $30 \%$ savings of irrigation water for establishment.

2015-16 Season. Average air temperature in September was $26.5^{\circ} \mathrm{C}$, with a maximum of $34{ }^{\circ} \mathrm{C}$ and a minimum of $21.2^{\circ} \mathrm{C}$. Compared with previous seasons, minimum air temperatures in Sept. and Oct. 2015 were warmer (Fig. 1). In Nov. and Dec. 2015, there was an average increment in air temperature of $5.1{ }^{\circ} \mathrm{C}$ compared with the 2014 15 season. Season cumulative rainfall was $478.2 \mathrm{~mm}$. Overall, the 2015-16 season was warmer than previous seasons, with reduced rainfall $(135 \mathrm{~mm}$ less) compared with the 2014-15 season (Fig. $1 \mathrm{~B}$ and C).

EARLY YIELD. Early yield was affected by planting date, establishment practice, and cultivar. Late September had the greatest early yield compared with mid September and early October. Establishment practice affected early yield; 10 DSI + kaolin clay and 7 DSI + kaolin clay had the greatest early yield compared with 10 DSI and 7 DSI. 'Florida 127 ' had a $20 \%$ greater early yield than 'Florida Radiance'. There was an interaction between planting date and establishment practice for fruit number. In mid September, 10 DSI + kaolin clay and 7 DSI + kaolin clay had the greatest number of early fruit per plant compared with 10 DSI and 7 DSI (Table 6). In late September, there was no difference among plants established with 10 DSI + kaolin clay, 7 DSI, and 7 DSI + kaolin clay (Table 6). In early October, plants established with 10 DSI, 10 DSI + kaolin clay, and 7 DSI + kaolin clay had a greater number of early fruit per plant compared with 7 DSI.

Total YIELD. Total fruit yield was unaffected by planting date, with an average of $10.6 \mathrm{Mg} \cdot \mathrm{ha}^{-1}$. However, there were main effects of establishment practice and cultivar on total yield (Table 7). For establishment practice, 10 DSI + kaolin clay, 7 DSI, and 7 DSI + kaolin clay had the greatest total yield, with an average of $10.9 \mathrm{Mg} \cdot \mathrm{ha}^{-1}$ (Table 7), whereas 10 DSI had a $12 \%$ less total yield. Overall, 'Florida 127' produced a $25 \%$ greater total yield than 'Florida Radiance' (Table 7).

\section{Discussion}

Results from three consecutive seasons of strawberry field trials in west-central Florida revealed that early yield was influenced by planting date, cultivar, and establishment practice.

In 2013-14, greater early yield of 'Floridal27' at earlier planting 
Table 4. Effect of planting date, establishment practice and cultivar on early yield, early fruit number and early average fruit weight of strawberry in Balm, FL for the 2014-15 and 2015-16 growing seasons.

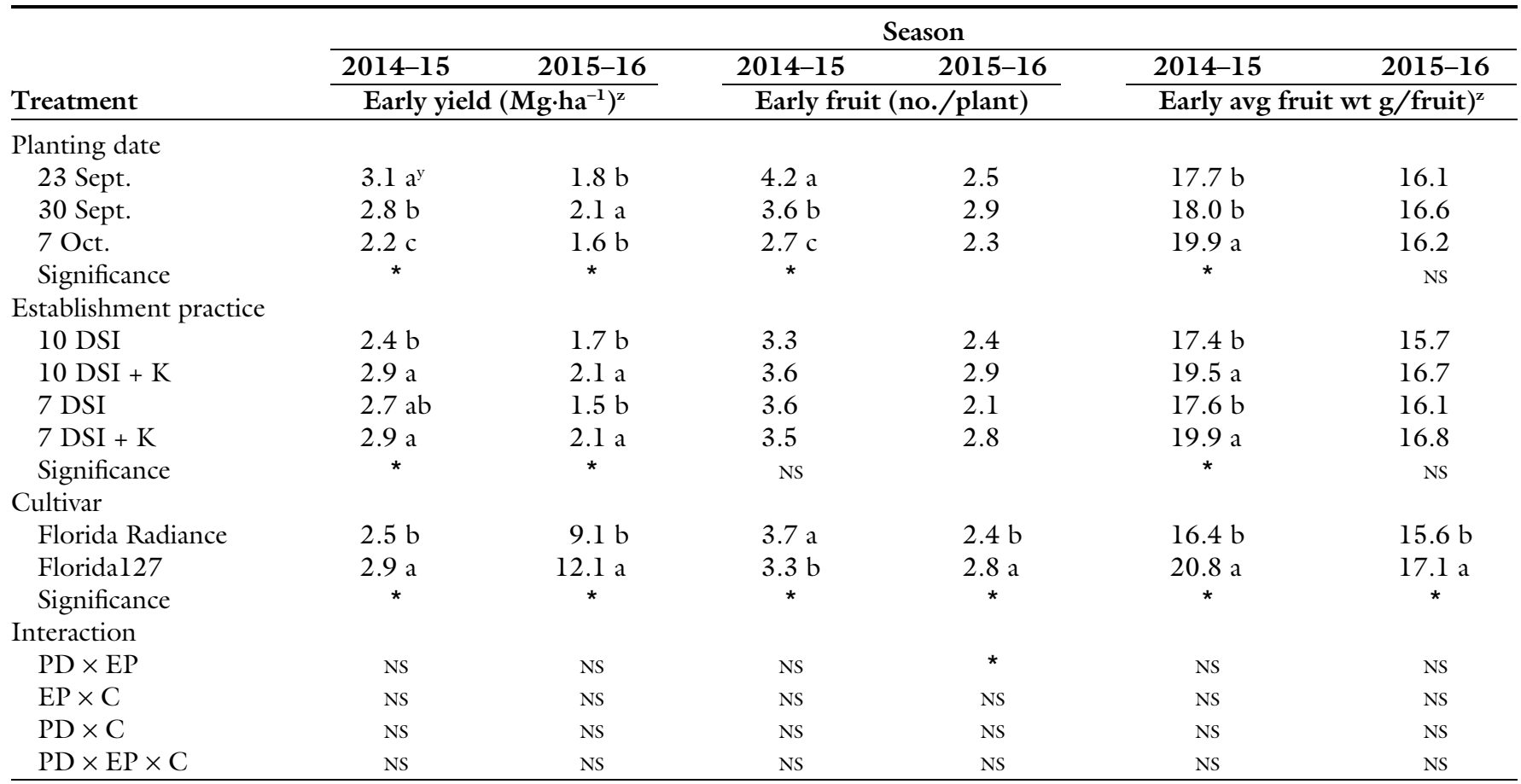

${ }^{\mathrm{z}} \mathrm{l} \mathrm{Mg} \cdot \mathrm{ha}^{-1}=0.4461 \mathrm{ton} / \mathrm{acre}, \mathrm{lg}=0.0353 \mathrm{oz}$.

y Values followed by the different letters (columns) indicate that the means of planting dates or establishment practice are significantly different $(P \leq 0.05)$ according to Fisher's protected least significant difference test within early yield, early fruit, or early average fruit weight.

NS, *Nonsignificant or significant at $P \leq 0.05$, respectively.

$\mathrm{DSI}=$ days of sprinkler irrigation; $\mathrm{K}=$ kaolin clay application on day 8 or 11 of establishment irrigation; $\mathrm{PD}=\mathrm{planting}$ date; $\mathrm{EP}=\mathrm{establishment}$ practice; $\mathrm{C}=\mathrm{cultivar}$.

Table 5. Effect of planting date, establishment practice and cultivar on total yield and total fruit number in strawberry in Balm, FL during the 2014-15 season.

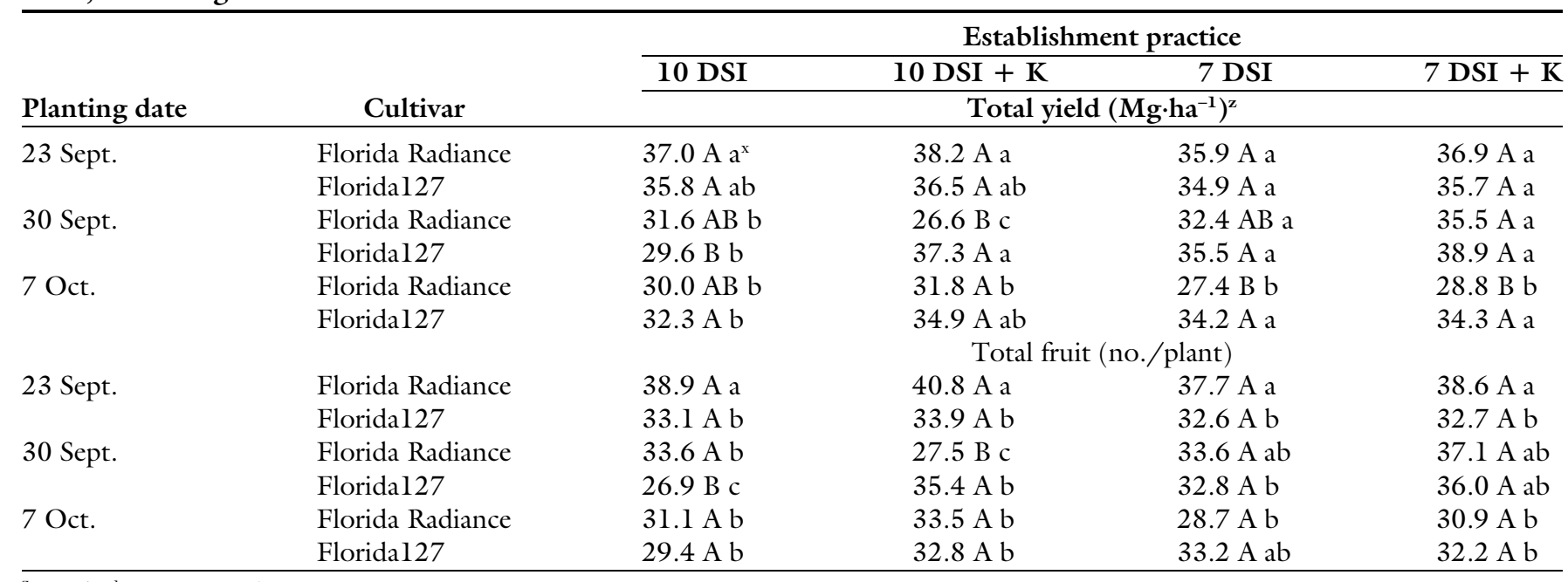

${ }^{\mathrm{z}} \mathrm{l} \mathrm{Mg} \cdot \mathrm{ha}^{-1}=0.4461$ ton/acre.

'Values followed by different uppercase letters (rows) indicate significantly different means ( $P \leq 0.05)$ according to Fisher's protected least significant difference (LSD) test within planting date and cultivar. Values followed by different lowercase letters (columns) indicate significantly different means $(P \leq 0.05)$ according to Fisher's protected LSD test within establishment practice.

DSI = days of sprinkler irrigation; $\mathrm{K}=$ kaolin clay application on day 8 or 11 of establishment irrigation.

dates could be attributed to an increase in the number of fruit per plant. The same pattern was observed in 2014-15 for all cultivars, when the mid-September planting had a greater fruit number than the two later planting dates.
Photoperiod and air temperature are the two most studied environmental factors affecting strawberry flowering (Darnell et al., 2003; Durner, 2016; Heide, 1977; Li et al., 2010; Rantanen et al., 2015; Sønsteby and Heide, 2017; Stewart and Folta, 2010; Sun et al., 2012). At nursery stage, all plants were acclimated to less than a 13-h photoperiod after 1 Sept. at MacDoel, CA. Similarly, after transplantation in Florida, plants were grown at photoperiods between 13 and $11 \mathrm{~h}$ throughout the season. Garcia and 
Kubota (2017) evaluated four cultivars classified as short-day plants, including 'Florida Radiance' and 'Floridal27'. Transplants were grown under 11, 12,13 , and $14 \mathrm{~h}$ at $17^{\circ} \mathrm{C}$ during an 8 -week period. Their results indicated that 'Florida Radiance' and 'Floridal27' had a critical photoperiod between 13 and $14 \mathrm{~h}$. Based on this premise, we concluded that our treatments were affected primarily by air temperature rather than photoperiod.

Early planting date treatments received fewer chilling hours than late planting dates. Under this condition, the only consistent cultivar with a greater early yield on early planting was Floridal 27, which received as low as $147 \mathrm{~h}$ of chilling and an increased early yield of $\approx 25 \%$ compared with later planting dates.

Palha et al. (2002) found a strong correlation between nonstructural carbohydrates in strawberry roots and early fruit yield in 'Chandler' and 'Douglas', suggesting that the quantity of root carbohydrates in freshly dug plants may be an important factor in determining early yield. Furthermore, Mendel and Smith (2012) reported a relationship between the concentration of nonstructural carbohydrates in the crown and roots, and the accumulation of chilling to less than $10^{\circ} \mathrm{C}$ in strawberry plants. Although the results of Mendel and Smith (2012) did not show a direct yield increment with increased nonstructural carbohydrates, the authors suggested that reserved nonstructural carbohydrates in strawberry partly reflect the productivity of the plant. Another point of assessment is the time before digging, as early planting may reduce the time for plant development at the nursery and

Table 6. Effect of planting date and establishment practice on early fruit number of strawberry in Balm, FL, during the 2015-16 growing season.

\begin{tabular}{llccc}
\hline & \multicolumn{4}{c}{ Early fruit (no./plant) } \\
\cline { 2 - 5 } Planting date & 10 DSI & 10 DSI + K & 7 DSI & 7 DSI + K \\
\hline 23 Sept. & $2.3 \mathrm{~B} \mathrm{a}^{\mathrm{z}}$ & $3.2 \mathrm{~A} \mathrm{a}$ & $1.8 \mathrm{~B} \mathrm{~b}$ & $2.9 \mathrm{~A} \mathrm{ab}$ \\
30 Sept. & $2.4 \mathrm{~B} \mathrm{a}$ & $3.1 \mathrm{~A} \mathrm{a}$ & $2.9 \mathrm{AB} \mathrm{a}$ & $3.3 \mathrm{~A} \mathrm{a}$ \\
7 Oct. & $2.6 \mathrm{~A} \mathrm{a}$ & $2.4 \mathrm{AB} \mathrm{b}$ & $1.7 \mathrm{~B} \mathrm{~b}$ & $2.3 \mathrm{AB} \mathrm{b}$ \\
\hline
\end{tabular}

${ }^{\mathrm{z}}$ Values followed by different uppercase letters (rows) indicate significantly different means $(P \leq 0.05)$ according to Fisher's protected least significant difference (LSD) test within planting date. Values followed by different lowercase letters (columns) indicate significantly different means $(P \leq 0.05)$ according to Fisher's protected LSD within establishment practice.

$\mathrm{DSI}=$ days of sprinkler irrigation; $\mathrm{K}=$ kaolin clay application on day 8 or 11 of establishment irrigation therefore the total nonstructural carbohydrates. Time in the nursery before establishment was not evaluated in this experiment.

It was considered that planting date treatments were a combination of days in the field after transplant and chilling accumulation hours before planting. Therefore, the increase in fruit number and early yield is most likely related to earlier development of previously induced flower buds resulting from sufficient chilling, and earlier development of side crowns of the bare-root transplants associated with earlier plant establishment. These results could be a consequence of the cooler chilling requirements in modern Florida cultivars.

Originally, it was hypothesized that the effect of kaolin clay on plant establishment and early yield was temperature dependent, as plant response to its application changes with the warmer air temperature associated with earlier planting. However, transplanting in Florida under warm air temperatures could have also affected the cultivar response to the planting date treatment, as flowering may have been inhibited by heat stress after establishment. Strawberry flowering response to air temperature is highly correlated to genotype (Stewart and Folta, 2010). During this experiment, there was an increase in average

Table 7. Effect of planting date, establishment practice, and cultivar on total yield, total fruit number, and total average fruit weight of strawberry in Balm, FL, during the 2014-15 and 2015-16 growing seasons.

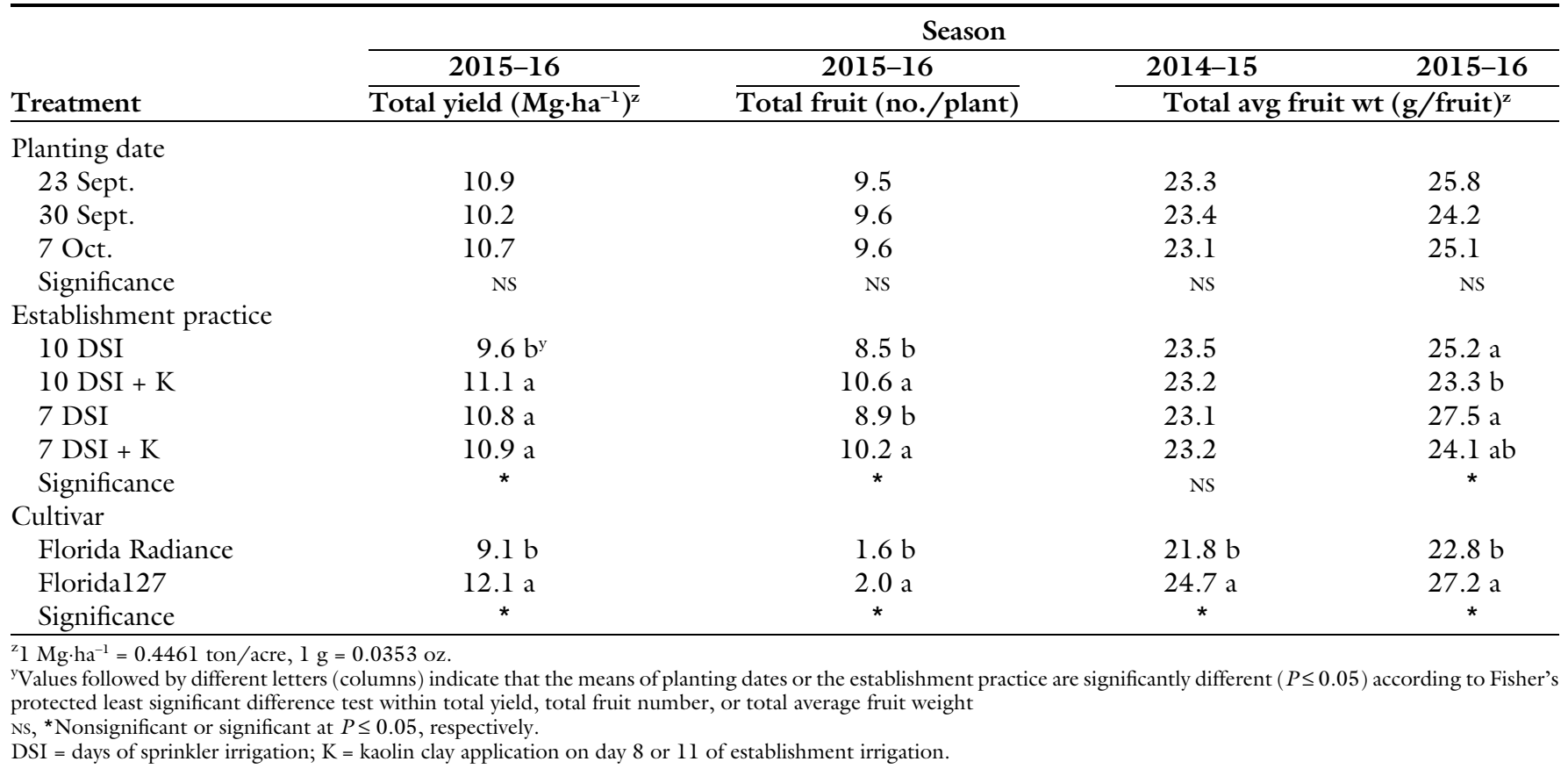


air temperature from 2014-15 to 2015-16, between September and November (Fig. IB and C). The fact that 'Floridal27' had a greater early yield in 2015-16 compared with 'Florida Radiance', regardless of the air temperature increment, suggests a greater heat tolerance of 'Floridal27'.

In terms of plant biomass, 'Floridal27' also had a greater biomass than 'Florida Radiance'. Similar to the findings of Sharpe et al. (2017), 'Floridal27' was 14\% wider and had $28 \%$ more leaves than 'Florida Radiance'. In our study, the increase in biomass of 'Floridal27' was partly related to runner production as 'Floridal 27 ' had $72 \%$ more runners than 'Florida Radiance' at 4 WAT. This, however, did not seem to have affected the early yield response of the cultivar. Bradford et al. (2010) stated that flowering inhibited runner production. However, the response seems to be cultivar dependent because runners and inflorescence production are not necessarily antagonistic processes in all short-day cultivars. Durner (2015) evaluated 'Cavendish', 'Chandler', 'Earliglow', 'Jewel', and 'Seneca' exposed to $0,1,2,3$, or 4 weeks of short days $(8 \mathrm{~h})$ at an average air temperature of $15^{\circ} \mathrm{C}$ (maximum, $20^{\circ} \mathrm{C}$; minimum, $12{ }^{\circ} \mathrm{C}$ ). Conditioned 'Cavendish' and 'Jewel' resulted in reduced runner production but not enhanced flowering. Flowering of 'Seneca' increased with conditioning whereas runner production decreased. In the case of 'Chandler', both flowering and runner production increased with 4 weeks of conditioning. This is applicable to Florida production systems, where running continued from season to season and is reduced under conditions of a short photoperiod and cooler temperatures (November to January).

Increased early yield resulting from the earlier establishment and development of plants in mid September could result in a significant increase in gross revenue for Florida strawberry growers. An estimate of the revenue benefit of early planting and increased early yield was calculated by multiplying the historical weekly price data for Florida fresh fruit (U.S. Department of Agriculture, 2012) from the past 10 seasons and the weekly yield data of both early planting (mid September) and late planting (early October) from this study. In this case, it was estimated that shifting from early October planting to mid-September planting could increase gross revenue up to $\$ 18,049 / \mathrm{ha}$, assuming a plant density of 43,635 plants/ha. The difference in gross revenue alone suggests that growers would benefit from shifting to earlier planting dates.

In terms of the establishment practice, no differences in early yield were found between 10 DSI (standard practice) and 7 DSI + kaolin clay foliar application at day 8 . This is similar to the results of Santos et al. (2012b), who compared strawberry yield in response to DSI and DSI + kaolin clay treatments, in which the greatest strawberry early fruit weight was achieved with either 6 DSI + kaolin clay, 8 DSI + kaolin clay, or 10 DSI, with yield ranging between 7945 and $8172 \mathrm{~kg} \cdot \mathrm{ha}^{-1}$. They suggested the response may be related to foliar application of kaolin clay reducing leaf and crown temperatures by reflecting solar radiation. This would decrease evaporation around strawberry crowns and leaf transpiration, thus allowing faster formation of new leaves and roots. Their conclusions were supported by previous studies indicating that kaolin clay application reduced warm air temperature stress and excessive transpiration in other crops (Glenn et al., 2002; Melgarejo et al., 2004; Wand et al., 2006).

However, in our study, during the 2015-16 season, there were minimal differences in air temperature between 7 DSI + kaolin clay $\left(25.6^{\circ} \mathrm{C}\right)$, and 7 DSI $\left(25.8^{\circ} \mathrm{C}\right)$ on top of the plastic bed, in-between the plastic mulch and the soil $(27.7$ vs. $27.0^{\circ} \mathrm{C}$ ), or at 4 inches of soil depth $\left(26.0\right.$ vs. $\left.26.7^{\circ} \mathrm{C}\right)$, although kaolin clay enhanced early yield in the 201415 and 2015-16 seasons. Thus, the kaolin clay effect on strawberry establishment may have little relation to air temperature around the strawberry crown. Further investigation on the effects of kaolin clay in strawberry is necessary to elucidate the potential benefits during and after establishment.

\section{Conclusions}

The objectives of this study were to define the earliest planting date to increase early strawberry production in west-central Florida and to assess the most adequate establishment practice for strawberry bare-root transplants. Early planting (mid September) increased the early yield of 'Floridal27' by $\approx 25 \%$, whereas the application of 7 DSI + kaolin clay resulted in a similar or greater early yield compared with 10 DSI. The 10 DSI practice uses up to $362.3 \mathrm{~mm}$ water during the first $10 \mathrm{~d}$ of establishment. However, the alternative practice of 7 DSI with an application of kaolin clay at day 8 could reduce water use for establishment by $30 \%$, representing a water savings of $108.7 \mathrm{~mm}$, with no detrimental effect on early or total yield.

In conclusion, mid-September planting resulted in an $\approx 25 \%$ increase in early yield of 'Floridal27' compared with early October traditional planting, with no difference in total yield. Furthermore, 7 DSI followed by the foliar application of kaolin clay at day 8 increased early yield by $19 \%$ compared with 10 DSI for strawberry establishment, with additional water savings of $108.7 \mathrm{~mm}$.

\section{Literature cited}

Bish, E.B. and D.J. Cantliffe. 2002. Temperature conditioning and container size affect early season fruit yield of strawberry plug plants in a winter, annual hill production system. HortScience 37:762-764.

Bish, E.B., D.J. Cantliffe, and C.K. Chandler. 2001. A system for producing large quantities of greenhouse-grown strawberry plantlets for plug production. HortTechnology 11:636-638.

Bish, E.B., D.J. Cantliffe, G.J. Hochmuth, and C.K. Chandler. 1997. Development of containerized strawberry transplants for Florida's winter production system. Acta Hort. 439(1):469-474.

Bradford, E., J.F. Hancock, and R.M. Warner. 2010. Interactions of temperature and photoperiod determine expression of repeat flowering in strawberry. J. Amer. Soc. Hort. Sci. 135:102-107.

Cantore, V., B. Pace, and R. Albrizio. 2009. Kaolin-based particle film technology affects tomato physiology, yield and quality. Environ. Expt. Bot. 66(2):279288.

Darnell, L.D., D.J. Cantliffe, D.S. Kirschbaum, and C.K. Chandler. 2003. The physiology of flowering in strawberry. Hort. Rev. 28:325-349.

Durner, E.F. 2015. Photoperiod affects floral ontogeny in strawberry (Fragaria $\times$ ananassa Duch.) plug plants. Scientia Hort. 194:154-159. 
Durner, E.F. 2016. Photoperiod and temperature conditioning of 'Sweet Charlie' strawberry (Fragaria $\times$ ananassa Duch.) plugs enhances off-season production. Scientia Hort. 201:184-189.

Florida Automated Weather Network. 2018. Report generator for Balm. 6 June 2018. <https://fawn.ifas.ufl.edu/data/reports/>.

Garcia, K. and C. Kubota. 2017. Flowering responses of North American strawberry cultivars. Proc. Intl. Strawberry Symp. Acta Hort. 1156:483-490.

Glenn, D.M., A. Erez, G.J. Puterka, and P. Gundrum. 2003. Particle films affect carbon assimilation and yield in 'Empire' apple. J. Amer. Soc. Hort. Sci. 128:356362 .

Glenn, D.M., E. Prado, A. Erez, J. McFerson, and G.J. Puterka. 2002. A reflective, processed-kaolin particle film affects fruit temperature, radiation reflection, and solar injury in apple. J. Amer. Soc. Hort. Sci. 127:188-193.

Glenn, D.M. and G.J. Puterka. 2005. Particle films: A new technology for agriculture. Hort. Rev. 31:1-44.

Heide, O.M. 1977. Photoperiod and temperature interactions in growth and flowering of strawberry. Physiol. Plant. 40(1):21-26.

Heide, O.M., J.A. Stavang, and A. Sønsteby. 2013. Physiology and genetics of flowering in cultivated and wild strawberries - A review. J. Hort. Sci. Biotechnol. 88(1):1-18.

Hochmuth, G., D. Cantliffe, C. Chandler, C. Stanley, E. Bish, E. Waldo, D. Legard, and J. Duval. 2006a. Containerized strawberry transplants reduce establishment period, water use and enhance early growth and flowering compared with bare-root plants. HortTechnology 16:46-54.

Hochmuth, G., D. Cantliffe, C. Chandler, C. Stanley, E. Bish, E. Waldo, D. Legard, and J. Duval. 2006b. Fruiting responses economics of containerized and bare-root strawberry transplants established with different irrigation methods. HortTechnology 16:205-210.

Kelly, K., V.M. Whitaker, and M.C.N. Nunes. 2016. Physicochemical characterization and postharvest performance of the new Sensation ${ }^{\circledR}$ 'Floridal27' strawberry compared to commercial standards. Scientia Hort. 211:283-294.

Li, H., T. Li, R.J. Gordon, S.K. Asieda, and K. Hu. 2010. Strawberry plant fruiting efficiency and its correlation with solar irradiance, temperature and reflectance water index variation. Environ. Expt. Bot. 68(2):165-174.

Melgarejo, P., J.J. Martınez, F.C. Hernandez, R. Martınez-Font, P. Barrows, and A. Erez. 2004. Kaolin treatment to reduce pomegranate sunburn. Scientia Hort. 100(1):349-353.

Mendel, C.M. and L. Smith. 2012. Relationship between the levels of nonstructural carbohydrates, digging date, nursery-growing environment, and chilling in strawberry transplants in subtropical environment. HortScience 47:459-464.

Palha, M.G.S., D.R. Taylor, and A.A. Monteiro. 2002. The effect of digging date and chilling history on root carbohydrate content and cropping of 'Chandler' and 'Douglas' strawberries in Portugal. Acta Hort. 567:511-514.

Poling, E.B. 1993. Strawberry plasticulture in North Carolina: II. Pre-plant, planting, and post planting considerations for growing 'Chandler' strawberry on black mulch. HortTechnology 3:383-393.

Rantanen, M., T. Kurokura, P. Jiang, K. Mouhot, and T. Hytönen. 2015. Strawberry homologue of terminal flowerl integrates photoperiod and temperature signals to inhibit flowering. Plant J. 82(1):163-173.

Rubinstein, J. 2015. Fragaria $\times$ ananassa: Past, present and future production of modern strawberry. 15 Mar. 2016. $<$ http://conservancy.umn.edu/ bitstream/handle/11299/175838/ Jared\%20Rubinstein\%20-\%20Strawberry. pdf? sequence $=1$ \&isAllowed $=y>$.

Santos, B.M., N.A. Peres, J.F. Price, C.K. Chandler, C.M. Whitaker, V.M. Whitaker, W.M. Stall, S.M. Olson, S.A. Smith, and E.H. Simonne. 2012a. Strawberry production in Florida, p. 271-282. In: S.M. Olson and B.M. Santos (eds.). Vegetable production handbook for Florida 2012. Univ. Florida, IFAS, Gainesville, FL.

Santos, B.M., T.P. Salame, and A.J. Whidden. 2012b. Reducing sprinkler irrigation volumes for strawberry transplant establishment in Florida. HortTechnology 22:224-227.

Sharpe, S.M., N.S. Boyd, P.J. Dittmar, G.E. MacDonald, R.L. Darnell, and J.A. Ferrell. 2017. Spray penetration into a strawberry canopy as affected by canopy structure nozzle type, and application volume. Weed Technol. 32(1):80-84.

Simonne, E.H. and M.D. Dukes. 2009 Principles and practices of irrigation management for vegetables, p. 17-23. In: S.M. Olson and E.H. Simonne (eds.). Vegetable production handbook for Florida 20092010. Vance Publishing, Lenexa, KS.

Sønsteby, A. and O.M. Heide. 2017. Flowering performance and yield of establishment and recent strawberry cultivars (Fragaria $\times$ ananassa) as affected by raising temperature and photoperiod. J. Hort. Sci. Biotechnol. 92(4):367-375.

Stewart, P.J. and K.M. Folta. 2010. A review of photoperiodic flowering research in strawberry (Fragaria spp.). Crit. Rev. Plant Sci. 29:1-13.

Sun, P., N. Mantri, H. Lou, Y. Hu, D. Sun, Y. Zhu, T. Dong, and H. Lu. 2012. Effects of elevated $\mathrm{CO}_{2}$ and temperature on yield and fruit quality of strawberry (Fragaria $\times$ ananassa. Duch) at two levels of nitrogen application. 12 Apr. 2017. <https://doi.org/10.1371/journal. pone.0041000>.

Tanino, K.K. and R. Wang. 2008. Modeling chilling requirement and diurnal temperature differences on flowering and yield performance in strawberry crown production. HortScience 43:2060-2065.

Torres-Quezada, E.A., L. Zotarelli, V.M. Whitaker, B.M. Santos, and I. HernándezOchoa. 2015. Initial crown diameter of strawberry bare-root transplant affects early and total fruit yield. HortTechnology 25:203-208.

U.S. Department of Agriculture. 2012. Table 6: U.S. strawberry prices received by growers, major states, by use, 1970-2012.21 Jan. 2017. <http://usda.mannlib.cornell. edu/MannUsda/viewDocumentInfo.do? documentID $=1381>$.

U.S. Department of Agriculture. 2017. 2015 State agriculture overview (Florida). 21 Jan. 2017. <https://www.nass.usda.gov/ Quick_Stats/Ag_Overview/stateOverview. php?state=FLORIDA $>$.

U.S. Department of Agriculture. 2018. Web soil survey. 22 Mar. 2018. <https:// websoilsurvey.sc.egov.usda.gov/>.

Wand, S.J., K.I. Theron, J. Ackerman, and S.J. Marais. 2006. Harvest and post-harvest apple fruit quality following applications of kaolin particle film in South African orchards. Scientia Hort. 107(3):271-276.

Whitaker, V.M., N.S. Boyd, N.A. Peres, J.W. Noling, and J. Renkema. 2017. Strawberry production, p. 293-312. In: G.E. Vallad, H.A. Smith, P.J. Dittmar, and J.H. Freeman (eds.). Vegetable production handbook for Florida 2017. Univ. Florida, IFAS. Gainesville, FL.

Whitaker, V.M., C.K. Chandler, and N.A. Peres. 2014. Sensation ${ }^{\mathrm{TM}}$ brand 'Floridal27' strawberry. 9 Jan. 2016. <http:// edis.ifas.ufl.edu/hs1256>.

Wu, F., Z. Guan, and A. Whidden. 2012. Strawberry industry overview and outlook. 5 Aug. 2013. <http://www.fred. ifas.ufl.edu/pdf/webinar/Strawberry. $\mathrm{pdf}>$. 